\title{
Fish migration and fish ramp assessment at a gauging station on a Mediterranean river (Catalonia, NE Iberian Peninsula)
}

\author{
Marc Ordeix
}

CERM, Center for the Study of Mediterranean Rivers, University of Vic - Central University of Catalonia. Ter River Museum. Passeig del Ter, 2. 08560 Manlleu, Catalonia (Spain).

*Corresponding author: marc.ordeix@museudelter.cat/marc.ordeix@uvic.cat

Received: 10/08/15

Accepted: 03/03/17

\begin{abstract}
Fish migration and fish ramp assessment at a gauging station on a Mediterranean river (Catalonia, NE Iberian Peninsula)

In May and October 2013, an in situ assessment of the fish ramp at the gauging station on the Fluvià River at Olot was performed, using different techniques to estimate the fish ramp's effectiveness. This fish ramp is one of the first in Catalonia (NE Iberian Peninsula) that follows international guidelines for fish passes and especially for fish ramps.

The fish ramp allowed passage of all native cyprinid species from this river. The crossing rates were higher in May (average of 7.9 ind./day for Barbus meridionalis and 3.8 ind./day for Squalius laietanus), a month associated with their spawning period, than in October (average of 4.6 ind./day for B. meridionalis and 1.0 ind./day for S. laietanus).

Pending complementary year-round samplings for several annual periods, the results show that the spawning period seems to be the primary driver of upstream fish migration, which is also influenced by a decrease in river flow just after a peak flow, a minimum water temperature value and less bright lunar phases.
\end{abstract}

Key words: Fish migration, freshwater fish, fish passes, fish ramps, assessment, Catalonia, Iberian Peninsula, Barbus meridionalis, Squalius laietanus, Mediterranean rivers, weirs, gauging stations.

\section{RESUMEN}

Migración de peces y evaluación de una rampa para peces en una estación de aforo en un río mediterráneo (Cataluña, NE Península Ibérica)

Durante los meses de mayo y octubre de 2013, se realizó una evaluación in situ de la rampa para peces de la estación de aforo del río Fluvià en Olot utilizando diferentes técnicas para estimar su eficacia. Esta rampa para peces es una de las primeras de Cataluña (NE Península Ibérica) que sigue directrices internacionales para dispositivos de paso para peces y, especialmente, para rampas para peces.

Esta rampa permitió el paso de todas las especies de ciprínidos autóctonos de este río. Las tasas de franqueo fueron más altas en mayo (media de 7.9 ind./día para Barbus meridionalis y 3.8 ind./día para Squalius laietanus), asociadas con su período de freza, que en octubre (media de 4.6 ind./día para B. meridionalis y 1.0 ind./día para S. laietanus).

Pendiente de muestreos complementarios realizables durante varios períodos anuales, el periodo de freza parece ser el principal impulsor de la migración río arriba, que también se ve influida por una disminución de caudal justo después de puntas de caudal, un mínimo de temperatura del agua y las fases lunares menos luminosas.

Palabras clave: Migración de peces, peces continentales, dispositivos de paso, rampas para peces, evaluación, Cataluña, Península Ibérica, Barbus meridionalis, Squalius laietanus, ríos mediterráneos, azudes, estaciones de aforo. 


\section{INTRODUCTION}

Fish migrate for different reasons or factors related to their conservation, including spawning, dispersion, feeding, refuge and displacement (Armstrong et al., 2010). Migrations do not occur at the same time for all species, even though spring and autumn are the main periods. Migrations may in fact be observed throughout the year if all species living in certain rivers or river reaches are considered (Baudoin et al., 2014).

For any one species, the intensity of migration will usually follow a seasonal pattern. This will vary depending on exactly where in the catchment area any obstruction is located, e.g., far up or down in the system. Migration at some life stages, particularly for spawning and dispersion, can occupy quite small windows of time (Armstrong et al., 2010).

It has been widely reported that the principal factors that influence fish migration behaviour include the sexual maturity and condition of the fish; water temperature; river flow; currents; hydrology and meteorology; diurnal/nocturnal rhythm, or photoperiod; and electric and magnetic fields. In addition, the range of cues used by fish during their migration is very wide, and these movement patterns are changeable, being related to other environmental variables such as tidal cycle, large oceanic features, moonlight, turbidity, salinity, water quality, and other imprinted or inherited information regarding a route (Lucas \& Baras, 2001). However, Mediterranean freshwater fish migration has not been much studied (Doadrio, 2001).

Currently, most fish can no longer migrate to complete their life cycle because their natural habitats have been modified by human activity. River obstacles cause direct effects on population biology, such as local extinctions due to a lack of dispersion and recolonization; genetic isolation; inaccessibility of spawning areas, feeding areas, refuges from predators and shelter areas; harmful environmental conditions, e.g., pollution, extensive floods, droughts; or other human disturbances and natural disasters (Lucas \& Baras, 2001). The existence of rivers with poor connectivity is considered to be a major cause of decline for many fish species in the inland waters of the Iberian Peninsula (Doadrio, 2001; Santo, 2005), in Europe as a whole (Bruslé \& Quignard, 2001; Larinier, 2002) and worldwide (Gough et al., 2012).

The reestablishment of river connectivity became a legal requirement under the Water Framework Directive (2000/60/EC) and the European Plan for Eel Recovery (Regulation 1100/ 2007). It is also considered extremely important for the conservation of endangered freshwater species, which is included in the Habitats Directive (92/43/CEE). However, the capacity of native fish fauna to use fish passes and their natural patterns of movement are still poorly understood (Marmulla \& Welcomme, 2002). Moreover, fish pass assessments could provide important knowledge regarding movement patterns (Lucas \& Baras, 2001; Roni, 2005).

Restoration plans for fish migration should pay proper attention to dam and weir removal, which is the most environmentally positive solution in the medium and long term (Gough et $a l ., 2012$ ). If the cultural value of the obstacle or its current use (hydropower, irrigation, etc.) does not allow for removal, then close-to-nature fish passes, such as lateral channels and fish ramps, which provide optimum conditions for a wider range of species, individuals and flows (Marmulla \& Welcomme, 2002), should be promoted.

In Catalonia, the migration routes of native fish, some of which are Iberian endemisms, have been damaged in past centuries. The Catalan Water Agency located 886 large obstacles in 2010 (according to its database), mostly small weirs and some dams, which seriously affect fish migration. During the period 2005 to 2010, a study of fish pass facilities in Catalonia (with a surface area of $32.000 \mathrm{~km}^{2}$ in the northeast Iberian Peninsula) was carried out through direct inspection of 95 fishways (present in 11\% of the total obstacles; partially published in Ordeix et al., 2011).

Using the River Connectivity Index (ICF, from the Catalan name Índex de Connectivitat Fluvial) (Solà et al., 2011), only 21 of the obstacles (22\%) were classified as being of "very good quality" and 16 (17\%) as having "good" 
connectivity, being either partial barriers or close-to-nature fish facilities. Usually, fish passes do not adequately address the requirements of native fish species because they are generally badly designed or poorly maintained (61\% of existing solutions). Only 7 obstacles (7\%) were rehabilitation solutions classified as close-to-nature fish passes (fish ramps) (partially published in Ordeix et al., 2011).

Close-to-nature device assessment in Catalan rivers is mostly still pending (with the exception of a fish ramp of the Ter River at Manlleu). Hence, there is interest in the fish ramp associated with the gauging station on the Fluvià River at Olot (EA013), renovated in 2010, which follows international guidelines for fish passes and especially for fish ramps (Gebler, 1998; Larinier, 2002; Marmulla \& Welcomme, 2002). The aims of this study were (1) to assess the effectiveness of the fish ramp on the Fluvià River (Mediterranean) during the cyprinid reproductive period, at other times and under different environmental conditions and (2) to improve the knowledge of the main causes of and capabilities for migration of several Mediterranean freshwater fish.

\section{METHODS}

\section{Study area}

The Fluvià River rises at an altitude of 1175 m in the Garrotxa region (NE Catalonia). It runs $99.5 \mathrm{~km}$ before flowing into the Mediterranean Sea, with a discharge of $264.41 \mathrm{Hm}^{3}$ /year (Water Catalan Agency database). Its basin does not include large dams (> $10 \mathrm{~m}$ high). However, there are 117 facilities that involve some kind of barrier for fish migration (Ferrer et al., 2009). The region's climate is Mediterranean mountainous, with an annual rainfall range of $850-1100 \mathrm{~mm}$. The winter is cold, with average temperatures

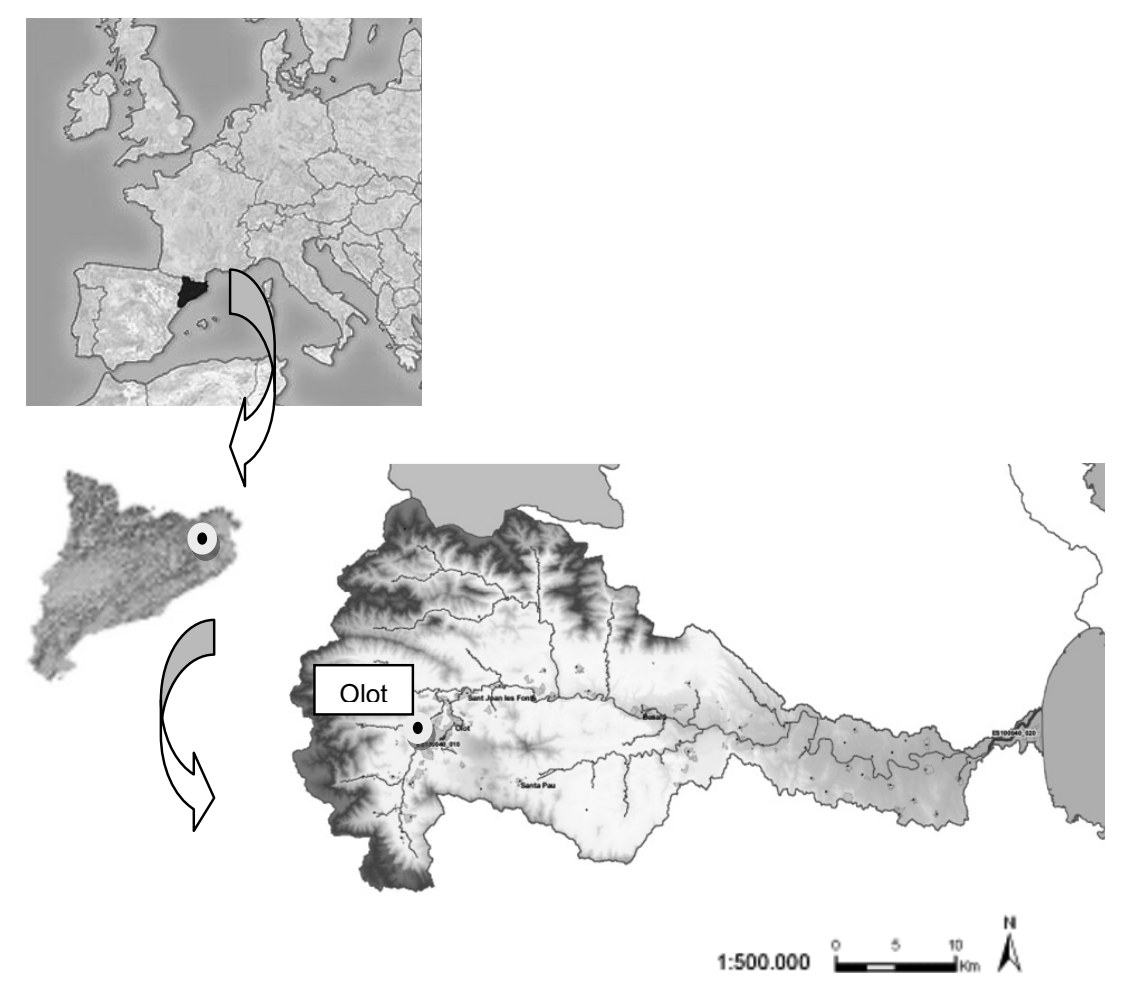

Figure 1. Study site (black dot), in the Fluvià River at Olot (NE Catalonia, NE Iberian Peninsula). Área de estudio (punto negro), en el río Fluvià en Olot (NE de Cataluña, Península Ibérica). 


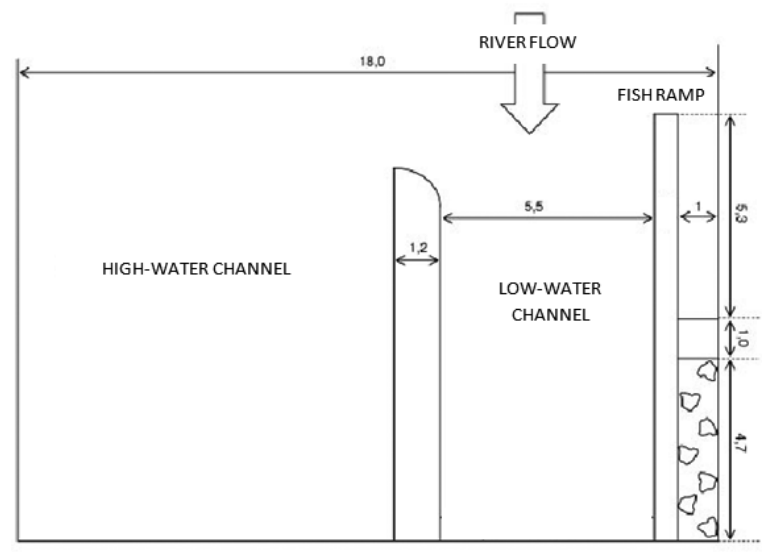

Figure 2. Illustration of the overhead shot and measures (in $\mathrm{m})$ of the gauging station EA013 on the Fluvià River at Olot (NE Catalonia). Ilustración de la vista cenital y medidas (en $\mathrm{m}$ ) de la estación de aforo EAO13 del río Fluvià en Olot (NE de Cataluña).

from $4{ }^{\circ} \mathrm{C}$ to $7{ }^{\circ} \mathrm{C}$, and summer is warm, between $17^{\circ} \mathrm{C}$ and $22^{\circ} \mathrm{C}$ (database of the Meteorological Service of Catalonia). Forest dominates the landscape, but extensive open ground (especially with corn) is also abundant.

The gauging station of the Fluvià River is located at an altitude of $398 \mathrm{~m}, 23 \mathrm{~km}$ from the river source and downstream of the town of Olot, in the Volcanic Area of the Garrotxa Natural Park (Fig. 1). There, the Fluvià River discharges $47.38 \mathrm{Hm}^{3} /$ year and has an average flow of $0.71 \mathrm{~m}^{3} / \mathrm{s}$ (range: $0.19-1.32 \mathrm{~m}^{3} / \mathrm{s}$ for the last 10 years) (Catalan Water Agency database).

This gauging station is $18.0 \mathrm{~m}$ wide, including a low-water channel of $5.5 \mathrm{~m}$ width and $0.3 \mathrm{~m}$ height and a close-to-nature fish pass, a fish ramp that is $1.0 \mathrm{~m}$ wide and $11.0 \mathrm{~m}$ long with a $10 \%$ slope (Fig. 2). To imitate the natural substrate, stones were spread along the ramp bottom. The weir includes an overhanging structure on top. The fish ramp entrance location (from downstream to upstream) is as close as possible to the weir.

\section{General data collection}

The assessment of barrier effects and fish migration was undertaken in two periods: (1) 29th April to 27th May 2013, during the expected spawning period and high migration activity of cyprinids (Sostoa et al., 1990; Doadrio, 2001), and (2) 5th October to 2nd November 2013, in order to collect information on fish movements outside their spawning period.

The fish pass effectiveness was assessed following useful previous criteria for Mediterranean rivers (Santos et al., 2006; Ordeix et al., 2011): (1) general data collection; (2) indirect estimation techniques, such as using trapping fishing systems to compare the fish population structure $100 \mathrm{~m}$ above and $100 \mathrm{~m}$ below the fish pass; and (3) direct estimation techniques, such as installing a fish trap at the water intake upstream of the fish ramp to compare the fish population structure and crossing rates with the fish population that was potentially present downstream. The latter was obtained by using electrofishing systems (depletion sampling; Zippin, 1958) in the 100-m stretch of the river immediately downstream of the gauging station, complemented by a daily collection of hydrological and environmental data.

River habitat and riparian vegetation indexes, IHF (Pardo et al., 2002), RBPs (Plafkin et al., 1989; Barbour et al., 2002) and QBR (Munné et al, 1998), were preliminarily obtained $100 \mathrm{~m}$ downstream and $100 \mathrm{~m}$ upstream of the gauging station. Daily physicochemical parameters (water temperature, electric conductivity, $\mathrm{pH}$ and dissolved oxygen) were calculated by using a multiparametric portable probe (YSI Professional Plus (Pro Plus), from YSI Incorporated, Yellow Springs, OH 45387, USA). The daily average river flow was reported by the Catalan Water Agency.

Several physical variables were measured daily at this hydraulic device, including the velocity, by using a flow probe (FP101, from Global Water Instrumentation, Inc., Gold River, CA 95670, USA); the operating levels of the fish pass; and the water depths and waterfall heights at the gauging station and at 7 sections of the fish ramp (in order to obtain medium and minimum values at each). To assess the theoretical degree of impediment for fish passage, the ICF index (River Connectivity Index; Solà et al., 2011) was also calculated. This index is based on comparisons of obstacle and fish pass 
(if any) characteristics, along with the capabilities to overcome the obstacle of the fish that are potentially present in the river section under consideration.

\section{Indirect estimation techniques}

Indirect estimation techniques used in this study consisted of a comparison of current fish populations $100 \mathrm{~m}$ upstream and $100 \mathrm{~m}$ downstream of the obstacle (Santos et al., 2006) by using two kinds of fish trapping systems (Travade \& Larinier, 2002; Roni, 2005) without bait: $c a$ maronera ( $2 \mathrm{~m}$ long, $0.006 \mathrm{~m}$ mesh size) and anguilera (3.5 m long, $0.010 \mathrm{~m}$ mesh size) (Clavero et al., 2006). Species composition and parameters such as size structure allowed the characterization of fish populations. The average somatic condition of the fish, fork length-total weight relationship, was also calculated. The fish trapping campaign was performed in October: at the new moon and the full moon.

\section{Direct estimation techniques}

A barrier effect was also deduced by comparing the fish population downstream (obtained by depletion sampling; Zippin, 1958) and fish captured at the water intake of the fish pass while migrating, mainly using fish crossing rates and deviations of size frequencies (Lucas \& Baras, 2001; Roni, 2005). The FL-TW relationship was also calculated. Electrofishing procedures (CEN standard norm UNE-EN 14011:2003), using Erreka III equipment (from Acuitec, 20150 Aduna, Gipuzkoa, Spain) with a Honda GXV50 motor $(220 \mathrm{~V}, 50 \mathrm{~Hz}$ and $2.200 \mathrm{~W})$, were employed to sample fish population downstream. A cross-section of the fish pass was completely blocked during two periods (May and October) by a fish trap $4.5 \mathrm{~m}$ long with $0.010 \mathrm{~m}$ mesh size, with a tight connection to the bottom, which was checked daily.

\section{Statistical analysis}

Deviations in the most abundant fish species size frequencies $100 \mathrm{~m}$ upstream and $100 \mathrm{~m}$ down- stream of the obstacle, as well as downstream and crossing the water intake upstream of the fish pass, were analysed by means of a Chi-square test. The mean sizes of fish between campaigns were also analysed by means of a Chi-square test. In both cases, the statistical package $R$ version 2.15.0 (2012-03-30; R Development Core Team, 2012) was used.

\section{RESULTS}

\section{Fish community}

In spring, the fish community downstream of the gauging station consisted of 4 species with an estimated density of 6720 ind./ha and a total biomass of $159 \mathrm{~kg} / \mathrm{ha}$ (obtained by depletion sampling). Two native species were common: Western Mediterranean barbel (Barbus meridionalis) (estimated downstream: 4614 ind./ha, 42.69 $\mathrm{kg} / \mathrm{ha}$, mean fork length (FL): $0.081 \mathrm{~m}$ (range: 0.019-0.167 m), mean weight: $16 \mathrm{~g}$ (range: 2$62 \mathrm{~g}$ ) and Catalan chub (Squalius laietanus) (estimated downstream: 896 ind./ha, $21.65 \mathrm{~kg} / \mathrm{ha}$, mean FL: $0.103 \mathrm{~m}$ (range: 0.019-0.202 m), mean weight: $38.1 \mathrm{~g}$ (range: $2-111 \mathrm{~g}$ ). Two non-native species were also present: Pyrenean minnow (Phoxinus bigerri) (estimated downstream: 1165 ind./ha, $1.32 \mathrm{~kg} / \mathrm{ha}$, mean FL: $0.038 \mathrm{~m}$ (range: 0.021-0.068 m), mean weight: $1.13 \mathrm{~g}$ (range: 1.20-3.70 g) and common carp (Cyprinus carpio) (estimated downstream: 45 ind./ha, $93.35 \mathrm{~kg} / \mathrm{ha}$, mean FL: $0.462 \mathrm{~m}$ (range: $0.444-0.480 \mathrm{~m}$ ), mean weight: $2084 \mathrm{~g}$ (range: 1790-2378 g). The fish community in autumn consisted of the same 4 species.

The average somatic condition (fork lengthtotal weight (FL-TW) relationship) was slightly lower in autumn than in spring. For B. meridionalis, it was $5.03 \mathrm{~mm} / \mathrm{g}$ in spring and $4.45 \mathrm{~mm} / \mathrm{g}$ in early autumn; for $S$. laietanus, it was 2.69 $\mathrm{mm} / \mathrm{g}$ in spring and $2.53 \mathrm{~mm} / \mathrm{g}$ in autumn; for $P$. bigerri, it was $33.25 \mathrm{~mm} / \mathrm{g}$ in spring and 17.72 $\mathrm{mm} / \mathrm{g}$ in autumn; and for C. carpio, it was 0.21 $\mathrm{mm} / \mathrm{g}$ in spring.

Based on catches (from traps and electrofishing), the B. meridionalis and S. laietanus spawn- 
ing period was at least from 10th May to 15th July. This information was not available for $P$. bigerri and C. carpio.

\section{Environmental data}

The river habitat was diverse and of very good quality both $100 \mathrm{~m}$ downstream and $100 \mathrm{~m}$ upstream of the gauging station, following the IHF (score of 93, downstream and upstream) and RBPs (score of 176, downstream and upstream) indexes. On the riverbed, boulders, stones and gravel were predominant. The riparian vegetation was mainly alder (Alnus glutinosa) and ash (Fraxinus excelsior) of good quality, following the QBR index (score of 90 downstream and 100 upstream).

In spring, the mean water flow $\left(1.290 \mathrm{~m}^{3} / \mathrm{s}\right)$, $\mathrm{pH}$ (8.4) and dissolved oxygen $(11.85 \mathrm{mg} / \mathrm{l})$ were higher and the water temperature was lower $\left(12.8^{\circ} \mathrm{C}\right)$ than in autumn (mean water flow: $0.161 \mathrm{~m}^{3} / \mathrm{s}, \mathrm{pH}$ : 7.9 , dissolved oxygen: $8.98 \mathrm{mg} / \mathrm{l}$, and water temperature: $14.6{ }^{\circ} \mathrm{C}$ ). The electrical conductivity was similar in spring $(520 \mu \mathrm{S} / \mathrm{cm})$ and autumn $(568 \mu \mathrm{S} / \mathrm{cm})$.

\section{Fish ramp}

During the study period, the difference in height between upstream and downstream water levels at the weir was $0.3-0.4 \mathrm{~m}$. The fish ramp had an appropriate entrance location (from downstream to upstream) as close as possible to the weir and an entrance pool with sufficient depth (0.37$0.57 \mathrm{~m})$.

This gauging station (with its fish ramp) was included in the very good quality of river connectivity for fish (score of 95), following the ICF

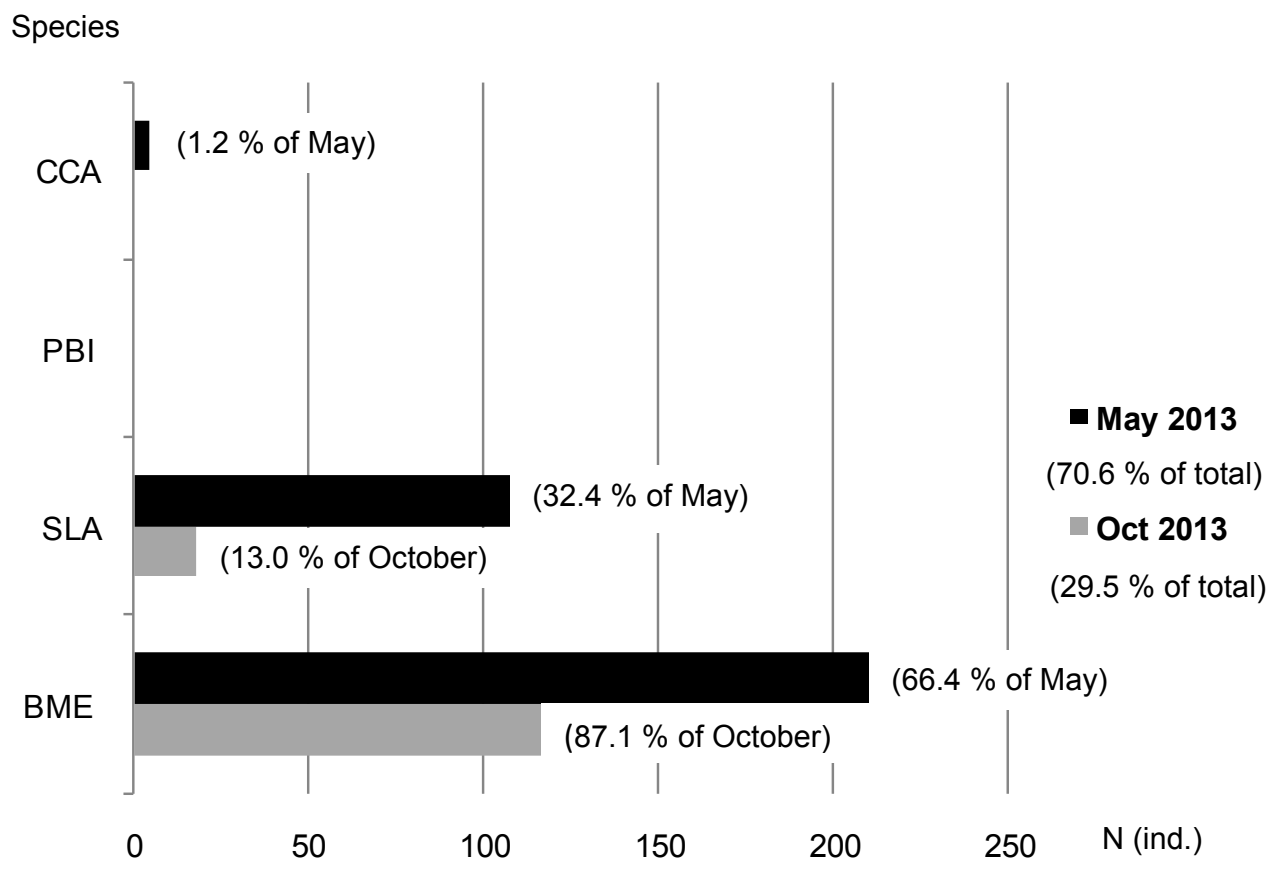

Figure 3. Species composition in number of individuals caught (and in percentage) obtained by trapping at the water intake upstream of the fish ramp at the gauging station EA013 on the Fluvià River at Olot (NE Catalonia) in May (27 days) and October 2013 (28 days). Chi-square test results (comparing catches between months) are $\chi^{2}=8 ; p=0.238$; df = 6. Legend: BME: Barbus meridionalis, SLA: Squalius laietanus, PBI: Phoxinus bigerri, and CCA: Cyprinus carpio. Composición de especies en número de individuos (y en porcentaje) obtenida mediante trampeo a la entrada del agua río arriba de la rampa para peces de la estación de aforo EA013 del río Fluvià en Olot (NE Cataluña) en mayo (27 días) y octubre de 2013 (28 días). Los resultados del test Chi-cuadrado (comparando las capturas entre los dos meses) son: $\chi^{2}=8 ; \mathrm{p}=0.238 ; d f=6$. Leyenda: BME: Barbus meridionalis, SLA: Squalius laietanus, $P B I$ : Phoxinus bigerri y CCA: Cyprinus carpio. 
Table 1. Size of species trapped at the water intake upstream of the fish ramp on the Fluvià River at Olot (NE Catalonia) in two study periods of 2013. Legend: BME: Barbus meridionalis, SLA: Squalius laietanus, and CCA: Cyprinus carpio. Tamaños de las especies capturadas a la entrada agua río arriba de la rampa para peces del río Fluvià en Olot (NE Cataluña), durante dos periodos de estudio de 2013. Leyenda: BME: Barbus meridionalis, SLA: Squalius laietanus y CCA: Cyprinus carpio.

\begin{tabular}{cccc}
\hline Species & BME & SLA & CCA \\
\hline $\begin{array}{l}\text { Mean fork } \\
\text { length (m) }\end{array}$ & & & \\
\hline May & 0.122 & 0.126 & 0.512 \\
\hline October & 0.118 & 0.132 & \\
\hline Mean & $\mathbf{0 . 1 2 1}$ & $\mathbf{0 . 1 2 7}$ & \\
\hline Range (m) & & & \\
\hline May & $0.048-0.173$ & $0.048-0.234$ & $0.435-0.604$ \\
\hline October & $0.069-0.198$ & $0.050-0.232$ & \\
\hline Mean & $\mathbf{0 . 0 4 8 - 0 . 1 9 8}$ & $\mathbf{0 . 0 4 8 - 0 . 2 3 4}$ & \\
\hline
\end{tabular}

index (Solà et al., 2011) and considering native intra-river migratory species (potamodromous) with a moderate capacity to overcome obstacles (G3a group, large cyprinid species or similar), large migratory species (catadromous; G2 group, eel), and intra-river migratory species (potamodromous) with a high capacity to overcome obstacles (G4 group, trout).

At times in spring ( $30 \%$ of the days, 8 days of 27) and often in autumn (75\% of the days, 21 days of 28), at one or more sections of this fish ramp, the water velocity was excessive $(>0.6 \mathrm{~m} / \mathrm{s})$ for small species with a low capacity to overcome obstacles (the ICF index's G3b group), such as $P$. bigerri. If this species was considered native, the gauging station would achieve only a moderate range of river connectivity quality (score of 75) under the ICF index. In addition, in autumn (dry and warm), a small waterfall appeared at the entry downstream of the fish ramp (average of $0.11 \mathrm{~m}$ and max. of $0.12 \mathrm{~m}$ ), but it never exceeded the maximum acceptable value $(0.20 \mathrm{~m})$ for this fish group (G3b).

\section{Migrating fish and fish ramp effectiveness}

Of 3 species, 472 fish were caught (using a fish trap) at the water intake upstream of the fish ramp during the whole study period (55 days), $70.5 \%$ of which were caught in spring and $29.5 \%$ in autumn (Fig. 3). B. meridionalis and S. laietanus were found on all occasions and C. carpio only in spring (Table 1).

B. meridionalis and S. laietanus exhibited a maximum crossing rate (Fig. 4) in spring (average of $7.9 \mathrm{ind} . /$ day and $3.8 \mathrm{ind}$./day, respectively) and a lower rate in autumn, slightly less for B. meridionalis (4.6 ind./day) and much less for S. laietanus (1.0 ind./day). The maximum fish passage occurred during the spawning period (around May), a few days after a high flow $\left(9.8 \mathrm{~m}^{3} / \mathrm{s}\right)$ and a rise in water temperature (until $14.6^{\circ} \mathrm{C}$ ) and at the new moon: 18.0 ind./day of $B$. meridionalis and 25.7 ind./day of S. laietanus. A secondary peak of passage was recorded in May two days after a moderate peak flow $\left(2.52 \mathrm{~m}^{3} / \mathrm{s}\right)$, with the water temperature rising (from 10.2 to $13.4{ }^{\circ} \mathrm{C}$ ) and during the moon's first quarter. Additionally, outside the spawning period, in October, the maximum fish crossing rates $(22.3$ ind./day of B. meridionalis and 6.0 ind./day of $S$. laietanus) were observed a few days after a moderate peak flow $\left(0.52 \mathrm{~m}^{3} / \mathrm{s}\right)$, with the water temperature rising (to $16.0^{\circ} \mathrm{C}$ ) and at the new moon.

C. carpio was detected crossing only in spring (average of 0.2 ind./day, maximum of 1.2 ind./day). P. bigerri, although abundant downstream, was never observed migrating (or spawning).

Movements were intense for $B$. meridionalis when the water temperature rose above $10^{\circ} \mathrm{C}$ and for S. laietanus and C. carpio when the water temperature rose above $13{ }^{\circ} \mathrm{C}$.

When fish pass rates were grouped by moon phases (Fig. 5), we found that $B$. meridionalis migrated with similar intensity throughout May (average range: $0.29-0.38$ ind./h), coinciding with increasing water temperature (average rate from $10.6^{\circ} \mathrm{C}$ to $14.5^{\circ} \mathrm{C}$ ) and decreasing water flow (average rate from 4.61 to $0.81 \mathrm{~m}^{3} / \mathrm{s}$ ) after a peak flow $\left(9.67 \mathrm{~m}^{3} / \mathrm{s}\right)$. In October, the crossing rate for $B$. meridionalis progressively decreased from the third quarter $(0.38 \mathrm{ind} . / \mathrm{h})$ to the full moon $(0.11$ ind./h), with regular water temperatures. 



Figure 4. Fish crossing rates (ind./h) through the fish ramp on the Fluvià River at Olot (NE Catalonia) in spring (spawning period; top) and autumn (bottom) 2013. Daily average river flows and water temperatures and moon phases are also shown. Legend: BME: Barbus meridionalis, SLA: Squalius laietanus, and CCA: Cyprinus carpio. Tasas de paso de peces (ind./h) a través de la rampa para peces del río Fluvià en Olot (NE Cataluña) en primavera-periodo de freza-(arriba) y otoño (abajo) de 2013. También se muestran las medias diarias de caudal del río y temperatura del agua, y las fases lunares. Leyenda: BME: Barbus meridionalis, SLA: Squalius laietanus y CCA: Cyprinus carpio.

S. laietanus (Fig. 5) migrated with different intensity between moon phases throughout May; its movements were especially intense during the new moon and the first quarter phases $(0.35$ ind./h and 0.12 ind./h, respectively), coinciding with an increase in water temperature and 


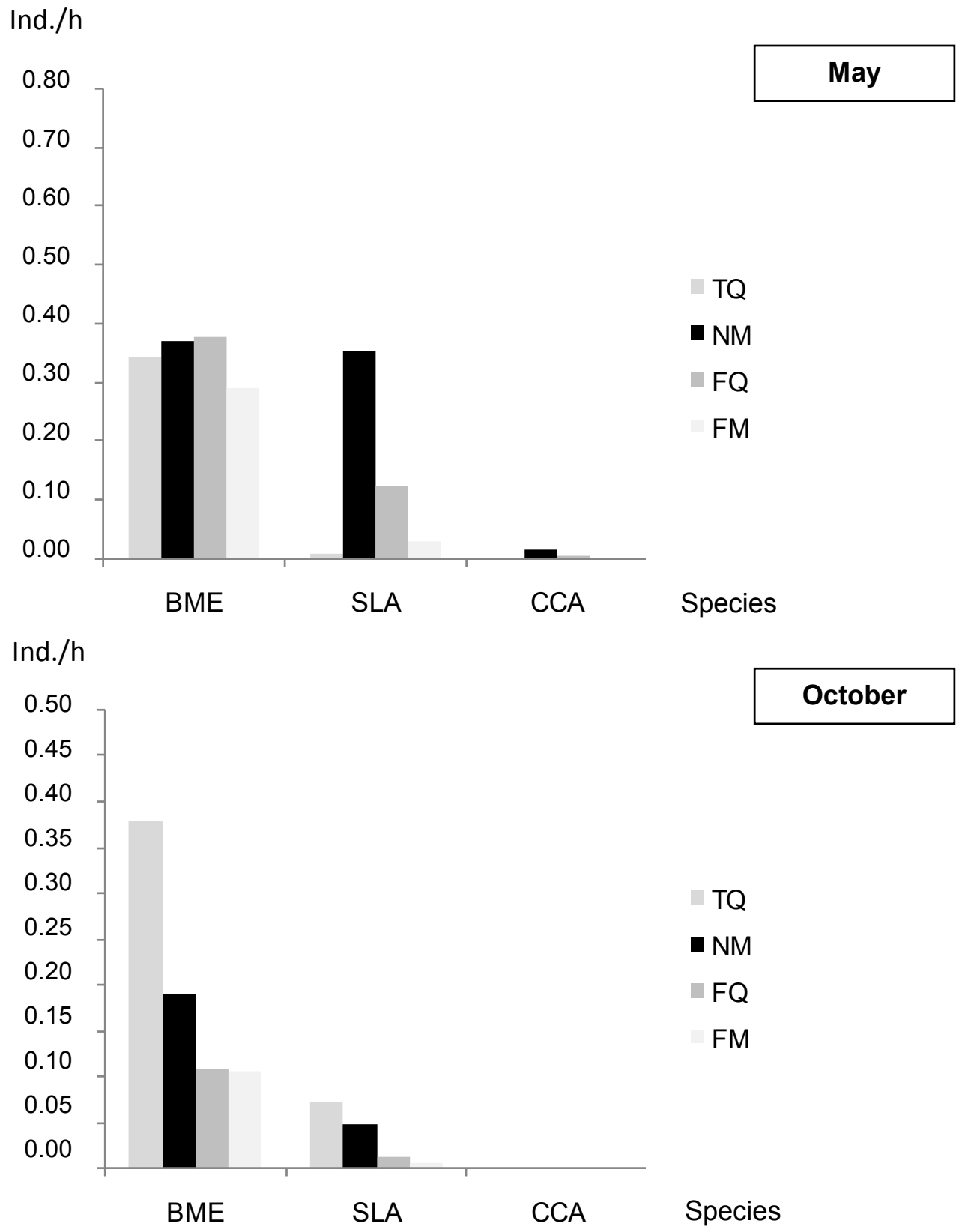

Figure 5. Fish crossing rates ((ind./h)*10) through the fish ramp on the Fluvià River at Olot (NE Catalonia), grouped per moon phases in May (spawning period; top) and October (bottom) 2013. In May, average river flow and water temperature for each moon phase (from third quarter (left) to full moon (right)) were: river flows $=4.61 \mathrm{~m}^{3} / \mathrm{s}, 0.81 \mathrm{~m}^{3} / \mathrm{s}, 1.52 \mathrm{~m}^{3} / \mathrm{s}$ and $1.02 \mathrm{~m}^{3} / \mathrm{s} ; \mathrm{wa}-$ ter temperatures $=10.6{ }^{\circ} \mathrm{C}, 14.5^{\circ} \mathrm{C}, 13.1^{\circ} \mathrm{C}$ and $13.0^{\circ} \mathrm{C}$. In October, river flows $=0.26 \mathrm{~m}^{3} / \mathrm{s}, 0.16 \mathrm{~m}^{3} / \mathrm{s}, 0.14 \mathrm{~m}^{3} / \mathrm{s}$ and $0.13 \mathrm{~m}^{3} / \mathrm{s} ; \mathrm{water}$ temperatures $=15.0^{\circ} \mathrm{C}, 13.3^{\circ} \mathrm{C}, 15.0^{\circ} \mathrm{C}$ and $15.0^{\circ} \mathrm{C}$. Legend: BME: Barbus meridionalis, SLA: Squalius laietanus, and CCA: Cyprinus carpio; TQ: third quarter, NM: new moon, FQ: first quarter, and FM: full moon. Tasas de paso de peces $(($ ind./h $) * 10)$ a través de la rampa para peces del río Fluvià en Olot (NE Cataluña), en total y agrupadas por fases lunares en mayo-periodo de freza-(arriba) y octubre (abajo) de 2013. En mayo, las medias de caudal del río y temperatura del agua para cada fase lunar eran: caudales=4.61 $\mathrm{m}^{3} / \mathrm{s}, 0.81 \mathrm{~m}^{3} / \mathrm{s}, 1.52 \mathrm{~m}^{3} / \mathrm{s}$ y $1.02 \mathrm{~m}^{3} / \mathrm{s}$; temperaturas del agua $=10.6^{\circ} \mathrm{C}, 14.5^{\circ} \mathrm{C}, 13.1^{\circ} \mathrm{Cy} 13.0^{\circ} \mathrm{C}$. En octubre, eran: caudales $=0.26$ $\mathrm{m}^{3} / \mathrm{s}, 0.16 \mathrm{~m}^{3} / \mathrm{s}, 0.14 \mathrm{~m}^{3} / \mathrm{s}$ y $0.13 \mathrm{~m}^{3} / \mathrm{s}$; temperaturas del agua $=15.0^{\circ} \mathrm{C}, 13.3^{\circ} \mathrm{C}, 15.0^{\circ} \mathrm{C}$ y $15.0^{\circ} \mathrm{C}$. Leyenda: BME: Barbus meridionalis, SLA: Squalius laietanus y CCA: Cyprinus carpio; TQ: cuarto menguante, NM: luna nueva, FQ: cuarto creciente y FM: luna llena. 

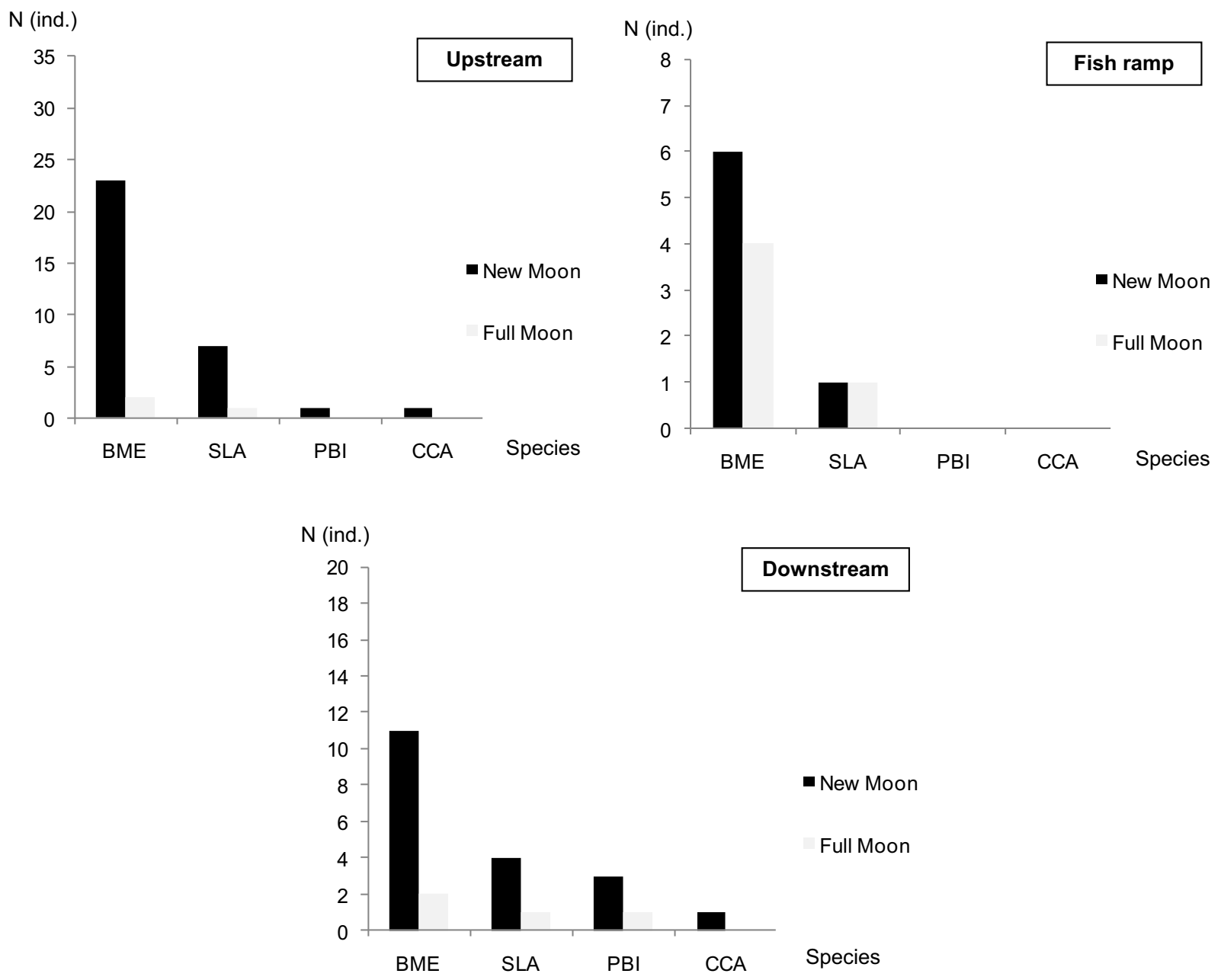

Figure 6. Species composition (in total numbers) obtained by fikenets $100 \mathrm{~m}$ upstream of the gauging station on the Fluvià River at Olot (NE Catalonia) (top), in the water intake upstream of the fish ramp of the gauging station (middle) and $100 \mathrm{~m}$ downstream of the gauging station (bottom), during new moon and full moon on 7th and 19th October 2013, respectively. Chi-square test results (comparing catches between new moon and full moon at each place) are upstream: $\chi^{2}=8 ; p=0.092$; df $=4$; fish ramp: $\chi^{2}=8$; $p=0.238$; df $=6$; downstream: $\chi^{2}=8 ; p=0.092$; df = 4. Legend: BME: Barbus meridionalis, SLA: Squalius laietanus, PBI: Phoxinus bigerri, and CCA: Cyprinus carpio. Composición de especies (en número total) obtenida mediante trampeo 100 m río arriba de la estación de aforo del río Fluvià en Olot (NE Cataluña) (arriba), a la salida río arriba de la rampa para peces de la estación de aforo (en medio) y $100 \mathrm{~m}$ río abajo de la estación de aforo (abajo), en luna nueva y luna llena, el 7 y el 19 de octubre de 2013, respectivamente. Los resultados del test Chi-cuadrado (comparando las capturas entre luna nueva y luna llena en cada lugar) son: río arriba: $\chi^{2}=8 ; \mathrm{p}=0.092 ; d f=4$; rampa para peces: $\chi^{2}=8 ; \mathrm{p}=0.238 ; d f=6$; río abajo: $\chi^{2}=8 ; \mathrm{p}=0.092 ; d f=4$. Leyenda: BME: Barbus meridionalis, SLA: Squalius laietanus, PBI: Phoxinus bigerri y CCA: Cyprinus carpio.

a decrease in water flow, and were greatly reduced during the full moon and the third quarter (average rates of $0.03 \mathrm{ind} . / \mathrm{h}$ and $0.01 \mathrm{ind} . / \mathrm{h}$, respectively). In October, its intensity was lower and progressively decreased from the third quarter $(0.07 \mathrm{ind} . / \mathrm{h})$ to the full moon $(0.01 \mathrm{ind} . / \mathrm{h})$. Data on C. carpio movements were scarce.

\section{Indirect estimation}

In October, the total catches obtained with traps on both sides of the gauging station on the Fluvià River (100 m upstream and $100 \mathrm{~m}$ downstream) were similar at the new moon (1.23 ind./h upstream and 0.76 ind./h downstream; $\chi^{2}=8$; 
$p=0.238 ; \mathrm{df}=6)$. The number of catches was low at the full moon $(0.13$ ind./h upstream and 0.17 ind./h downstream), so the differences between the two sides were uncertain $\left(\chi^{2}=5\right.$; $p=0.287 ; \mathrm{df}=4)$. Otherwise, statistically significant differences in numbers between the full moon and new moon catches were observed (Fig. 6). The river flow $\left(0.18 \mathrm{~m}^{3} / \mathrm{s}\right.$ and $0.14 \mathrm{~m}^{3} / \mathrm{s}$, respectively) and water temperature $\left(15.0^{\circ} \mathrm{C}\right.$ and $14.8^{\circ} \mathrm{C}$, respectively) were almost equal at the full moon and the new moon.

\section{Direct estimation}

Many individuals of B. meridionalis (221 ind. in May and 121 ind. in October) and S. laietanus (108 ind. in May and 18 ind. in October) and some of $C$. carpio (4 ind. in May and 0 ind. in

\section{Downstream}

\section{Fish ramp}

\section{May 2013}

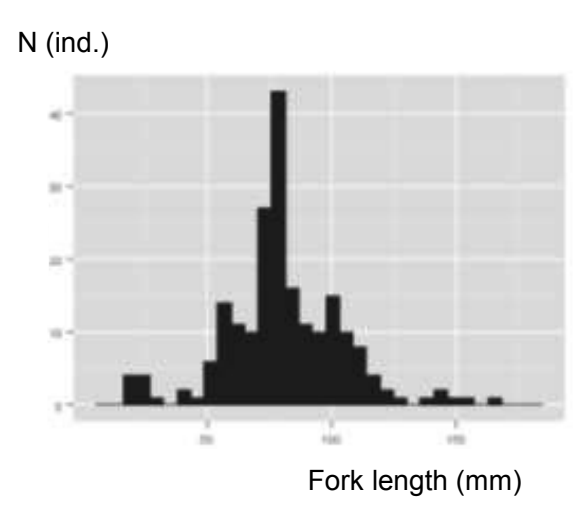

\section{$\mathrm{N}$ (ind.)}

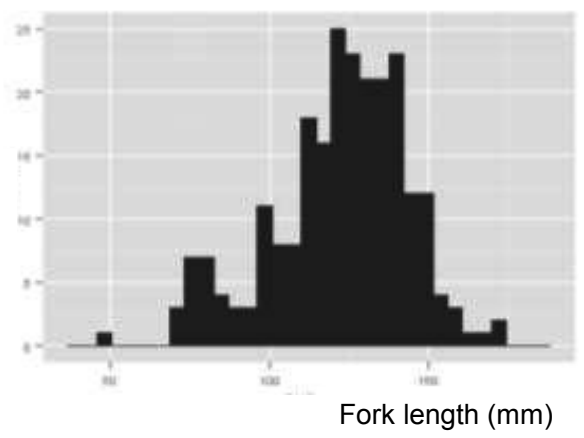

October 2013

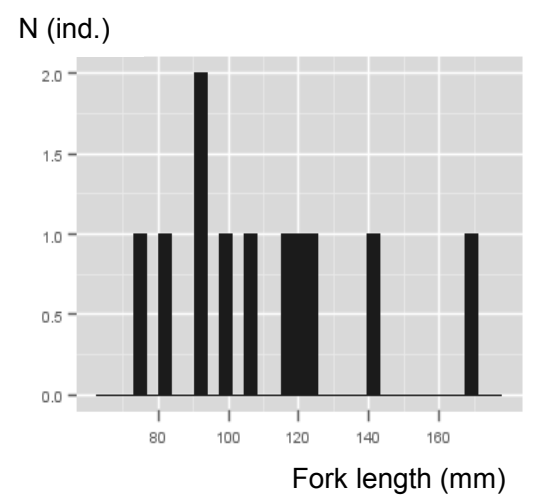

$\mathrm{N}$ (ind.)

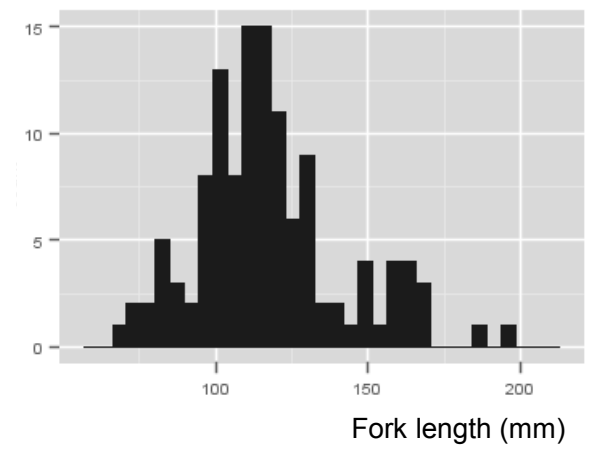

Figure 7. Barbus meridionalis size class frequencies (fork length, $\mathrm{mm}$ ) downstream (left) and in the water intake upstream of the fish ramp on the Fluvià River at Olot (NE Catalonia) (right) in May 2013 (top) and October 2013 (bottom). Average river flow and water temperature of May and October, respectively, were river flow $=1.290 \mathrm{~m}^{3} / \mathrm{s}$ and $0.161 \mathrm{~m}^{3} / \mathrm{s}$; water temperature $=12.0{ }^{\circ} \mathrm{C}$ and $14.6^{\circ} \mathrm{C}$. Chi-square test results (comparing size class frequencies between downstream and in the water intake upstream of the fish ramp) are: May: $\chi^{2}=340.347 ; p<0.001 ; \mathrm{df}=24$; October: $\chi^{2}=88 ; p=0.253$; $\mathrm{df}=80$. Frecuencias de talla de Barbus meridionalis (longitud furcal, $\mathrm{mm}$ ) río abajo (izquierda) y a la entrada del agua río arriba de la rampa para peces del río Fluvià en Olot (NE Cataluña) (derecha) en mayo de 2013 (arriba) y octubre de 2013 (abajo). Las medias de caudal del río y temperatura del agua de mayo y octubre, respectivamente, fueron: caudal del río= $1.290 \mathrm{~m}^{3} / \mathrm{s}$ y $0.161 \mathrm{~m}^{3} / \mathrm{s}$; temperatura del agua $=12.0^{\circ} \mathrm{C}$ y $14.6^{\circ} \mathrm{C}$. Los resultados del test Chi-cuadrado (comparando las frecuencias de talla entre río abajo y a la entrada río arriba de la rampa para peces) son: en mayo: $\chi^{2}=340.347 ; \mathrm{p}<0.001 ; d f=24$; en octubre: $\chi^{2}=88 ; \mathrm{p}=0.253 ; d f=80$. 
October) were caught at the water intake upstream of the fish ramp (Fig. 3). However, both species of native cyprinid showed statistically significant differences in fork length between individuals downstream and those migrating upstream (using the fish ramp) in spring ( $S$. laietanus: $\chi^{2}=31.793 ; p<0.001 ; \mathrm{df}=8 ; B$. meridionalis: $\chi^{2}=340.347 ; p<0.001$; df $=24$; Fig. 7); the individuals who negotiated the fish ramp were larger than those present downstream. Despite the modest number of catches in autumn, young-of-the-year B. meridionalis $(\mathrm{FL}<0.07 \mathrm{~m}$; Fig. 7) and S. laietanus (FL $<0.08 \mathrm{~m}$ ) mostly did not move upstream using the fish ramp during these two periods.

The average somatic condition of the fish migrating upstream using the fish ramp was slightly lower in autumn than in spring. For B. meridionalis, it was $3.83 \mathrm{~mm} / \mathrm{g}$ in spring and $3.11 \mathrm{~mm} / \mathrm{g}$ in autumn. For S. laietanus, it was $4.45 \mathrm{~mm} / \mathrm{g}$ in spring and $2.53 \mathrm{~mm} / \mathrm{g}$ in autumn. For Cyprinus carpio, it was $0.21 \mathrm{~mm} / \mathrm{g}$ in spring; none were caught in autumn.

\section{DISCUSSION}

\section{Fish community}

The Fluvià River includes a small number of freshwater fish species, such as other Mediterranean small and medium river basins (Bruslé \& Quignard, 2001). Brown trout (Salmo trutta), B. meridionalis, S. laietanus and European eel (Anguilla anguilla) were cited in the Garrotxa region in the past (Nadal-Fortià, 1964). In 2008, a sampling showed that $B$. meridionalis was present everywhere (Clavero et al., 2008), S. laietanus was also present but not abundant and $A$. anguilla and S. trutta were still present. C. carpio was the only exotic fish living there.

A. anguilla was not found in the present study. The absence of this tolerant, widely distributed species throughout the sampling campaigns and its shortage in previous samplings (Clavero et al., 2008) mainly associated with restocking indicate that the Fluvià River is still too fragmented and poorly connected with the Mediterranean Sea.
S. trutta was also not found. It was released during previous decades in large numbers from fish farms, but such releases are no longer allowed. Global warming could also affect the increase in water temperature recorded in recent decades in Iberian rivers, which appears to be associated with the decline of brown trout (Almodóvar et al., 2012).

The observed fish density and biomass (over 1500 individuals and $100 \mathrm{~kg}$ per ha, respectively) are considered good for populations in Iberian rivers (Sostoa et al., 2010). However, diagrams of the size class frequencies of $B$. meridionalis reflect a certain dominance of the age group young-of-the-year, with an average length remaining below $0.100 \mathrm{~m}$. This may be associated with fluctuating populations that are subject to frequent disturbances (Clavero et al., 2008).

The fact that the size class of fish found downstream of the gauging station was slightly different than that of the fish able to overcome the ramp during the spawning period does not necessarily indicate a malfunctioning of the fish passage; the difference could be related to reproductive or young individuals remaining in lower areas because they have suitable habitat downstream to fulfil their reproductive/feeding needs.

The slight decrease of the somatic condition of the fish between spring and early autumn could be associated with the better food availability in spring and summer in a watercourse with a high availability of oxygen and riparian vegetation (Vila-Gisbert et al., 2000); this suggestion coincides with other studies in this locality (Clavero et al., 2008) and other rivers in NE Catalonia (Ordeix et al., 2011). The average somatic condition was also slightly lower for $B$. meridionalis crossing the fish ramp, which are probably the healthiest population.

Although the observed spawning period of $B$. meridionalis and $S$. laietanus (at least between 10th May and 15th July 2013) coincides well with previous information (Sostoa et al., 1990; author's unpublished data), the spawning period could be initiated as early as March (Zamora et al., 2011). The Cyprinus carpio spawning period occurs between April and July (Sostoa et 
$a l ., 1990$; author's unpublished data), and the $P$. bigerri spawning period occurs between April and July (Doadrio, 2001; Leunda et al., 2010; author's unpublished data). Therefore, these species were detected crossing the fish ramp mainly during this period, except $P$. bigerri, although it is abundant downstream. This could be related to the fact that the sampling period did not coincide with the spawning period of $P$. bigerri in 2013; it had probably been delayed by low water temperatures in May.

\section{Fish ramp}

The fish ramp of the gauging station on the Fluvià River at Olot is very effective for all native fish species. The results of the quick assessment procedures based on the ICF index agree with the observed fish pass effectiveness for large cyprinid species, which are intra-river migratory species (potamodromous) with a moderate capacity to overcome obstacles (B. meridionalis and S. laietanus) using indirect and direct techniques. A. anguilla could also theoretically use the fish ramp and is able to pass along the riverbank as well.

Large individuals of $C$. carpio, an invasive species, were also observed migrating through this fish ramp, coinciding with a previous fish ramp assessment in Catalonia (minimum FL of $0.436 \mathrm{~cm}(n=18)$ in the Ter River at Manlleu, NE Catalonia, with an ICF index of 85 in May 2012 (author's unpublished data).

$P$. bigerri, an intra-river migratory species with a low capacity to overcome obstacles, non-native to this basin, was never observed crossing the fish ramp. The water velocity into the fish ramp could be too high $(>0.6 \mathrm{~m} / \mathrm{s})$ to be negotiated by smaller fish.

Although larger individuals prevail slightly over younger in crossing the fish ramp, the populations from the two sides of the gauging station are almost equivalent, and a barrier effect (following Solà et al., 2011) is not clearly observed.

When the waterfalls do not exceed $0.10 \mathrm{~m}$ in height and/or the water velocity is lower than $0.5 \mathrm{~m} / \mathrm{s}$, most species and individuals are able to cross a fish pass, including small species with low capacity to overcome obstacles, such as $P$. bigerri, A. anguilla and young-of-the-year of $S$. trutta and $B$. meridionalis, according to previous data from several fish passes in Catalonia (Ordeix et al., 2011). However, if the fish pass waterfalls are higher than $0.2 \mathrm{~m}$ and/or the water velocity is higher than $2 \mathrm{~m} / \mathrm{s}$, only the largest individuals of species with great ability to overcome obstacles, such as brown trout, or moderate ability, including some cyprinid species such as B. meridionalis ( $\mathrm{FL}>0.13 \mathrm{~m})$ and $S$. laietanus, are able to cross upstream (Ordeix et al., 2011). However, water velocities of $1.0-1.2 \mathrm{~m} / \mathrm{s}$ at the downstream entrance are also accepted by smaller Iberian cyprinids (Santos et al., 2005).

Therefore, we cannot ignore the possibility that the small waterfall $(>0.10 \mathrm{~m})$ that appeared at the entry downstream of the fish ramp during very low flows, and especially several water velocities inside the fish $\mathrm{ramp}(>0.5 \mathrm{~m} / \mathrm{s})$, could temporally affect part of the surrounding fish population, at least in their home range.

\section{Fish migration}

The observed crossing rates of $B$. meridionalis in the fish ramp in May (average of 7.9 ind./day) and October (average of 4.6 ind./day) are significant (the maximum known in Catalonia to date). Despite the interannual variability of Mediterranean species, previous studies in rivers of similar size and with the same species showed a slightly lower average. In the Llémena Stream in the Ter River basin, the range was 1.3-3.0 ind./day in spring and 0.2 ind./day in autumn (Ordeix et al., 2011), and many individuals (mostly males, with a smaller size than females) had difficulties in crossing. Although the passage rate depends on the population size of the migratory fish and on the size of the river, higher values were obtained for other cyprinids, especially in spring, as in the case of Iberian barbel (Luciobarbus bocagei) in a tributary of the Duero River in the north of Spain, with a range of 0.5-14.0 ind./day (Sanz et al., 2013).

Most Iberian freshwater fish migrate before and/or after the spawning period, but they also 
move a lot outside these periods. The available information focuses especially on upstream fish migration.

The most important fish migration periods for native Iberian freshwater fish (syngnathids, cyprinids, clupeids, acipenserids, pleuronectids and moronids) are spring and early summer. For example, $51.9 \%$ of the total observations of L. bocagei and $77 \%$ of Iberian nase (Pseudochondrostoma polylepis) in the Lima River (N Portugal; Santos et al., 2005) were registered around March-April.

Significant movements of fish were associated mostly with their particular spawning periods and following high or moderate peak flows, as indicated by many studies (Reiser \& Peacock, 1985; Lucas \& Baras, 2001; Marmulla \& Welcomme, 2002). The passage rates of freshwater Iberian cyprinids are very high in spring (AprilJune), with a peak passage in May, associated with their spawning period, but not only then (Santos et al., 2012; author's unpublished data).

Changes in river flow and current may influence when fish migrate, providing visual, tactile and inertial cues (Lucas \& Baras, 2001). High water discharge, often mixed with additional stimuli (temperature, photoperiod, etc.) to concert movement in a single direction, may stimulate fish to ascend rivers and can also stimulate fish movement in lakes, estuaries and coastal environments.

Water temperature seems to be an important factor in driving cyprinids upstream, highlighting its importance as a cue that controls the intensity of fish migration (Rodriguez-Ruiz \& Granado-Lorencio, 1992). In the Lima River (N Portugal; Santos et al., 2012), water temperature is the most important factor stimulating the upstream movement of cyprinids in spring, namely, $L$. bocage $i$ and $P$. duriense; they start to migrate at water temperatures above $15^{\circ} \mathrm{C}$ and $12-14^{\circ} \mathrm{C}$, respectively. L. bocagei and P. polylepis also move upstream of the Santa Teresa reservoir in the Tormes River (Duero Basin, Spain; Sanz et al., 2013) at water temperatures above $15^{\circ} \mathrm{C}$ and $17^{\circ} \mathrm{C}$, respectively. The crossing rates of Iberian cyprinids increase significantly when the water temperature rises above $13{ }^{\circ} \mathrm{C}$ (Santos et al.,
2012; Sanz et al., 2013; author's unpublished data from the Ter River).

In relation to the lunar cycle, large differences in fish activity between the new moon and the full moon were observed for all species, both in upstream and downstream river stretches and through the fish ramp. In May, coinciding with the spawning period, it seems that B. meridionalis is very active throughout the lunar cycle. In October, it seems that it moves mostly in the third quarter and the new moon. Although the reproduction of B. meridionalis could occur during the day and at night, a largely nocturnal behaviour outside the spawning season has been described (Poncin, 1994).

Fish activity during less bright moon phases coincides with the fact that Iberian cyprinids, i.e., L. bocagei, P. polylepis and Iberian chub (Squalius carolitertii), among others, i.e., $S$. trutta and $P$. marinus, show significant nocturnal preferences in their upstream movements (Santos et al., 2005; Sanz et al., 2013). Their migrations occur mainly at night and in twilight periods, when the chances of avoiding visual predators are presumably higher (Prignon et al., 1998).

\section{CONCLUSIONS}

We highlight the fact that the physical conditions of the fish ramp at the gauging station on the Fluvià River at Olot (NE Catalonia), which is part of the very good quality of river connectivity for fish (score of 95) under the ICF index (Solà et al., 2011), allow the passage of the native cyprinid species in this river, at least in spring and autumn. Large individuals of C. carpio, an invasive species, were also observed migrating through this fish ramp in spring. P. bigerri, the other non-native species in this river basin, was never observed crossing.

Otherwise, young-of-the-year B. meridionalis and S. laietanus seem not to move or to have difficulties in migrating upstream using the fish ramp. We cannot ignore the possibility that the small waterfall $(>0.10 \mathrm{~m})$ that appeared at the entry downstream of the fish ramp during very low flows, and especially several water velocities 
inside the fish $\mathrm{ramp}(>0.6 \mathrm{~m} / \mathrm{s})$, related to the small size of these fish (and hence lower swimming performance), could temporally affect part of the surrounding fish population.

Despite the interannual variability of Mediterranean species, the fish crossing rates in the Fluvià River at Olot are significant and very high in spring (May), associated with the spawning period of native freshwater cyprinids and coinciding with findings for other Mediterranean inland waters. The fish crossing rates of native cyprinids are lower but also important in autumn (October).

Pending complementary year-round samplings over several years, the spawning period seems to be the primary driver of upstream fish migration for these cyprinids, but a decrease in river flow following a peak flow, a minimum value of water temperature (above $10{ }^{\circ} \mathrm{C}$ for $B$. meridionalis and $13{ }^{\circ} \mathrm{C}$ for $S$. laietanus and $C$. carpio) and less bright lunar phases seem to also be important.

\section{ACKNOWLEDGMENTS}

To the members of the Catalan Water Agency, Juan José Villegas, Ramon Pintó and Antoni Munné, and the biologist of Volcanic Area of the Garrotxa Natural Park, Emili Bassols. To the UAB researcher, Maria Constenla, and the Forest Sciences Centre of Catalonia researcher, Jordi Camprodon, for their facilities and interest. To many colleagues of the Center for the Study of Mediterranean Rivers (CERM), Núria Sellarès, Laia Jiménez, Èlia Bretxa and Francesc Llach, and many trainees, who helped in fieldwork and data processing. To my family for sharing several weekends of fish pass monitoring.

\section{REFERENCES}

ALMODÓVAR, A., G.G. NICOLA, D. AYLLÓN \& B. ELVIRA. 2012. Global warming threatens the persistence of Mediterranean brown trout. Global Change Biology, 18: 1549-1560, doi: 10.1111/ j.1365-2486.2011.02608.x
ARMSTRONG, G.S., M.W. APRAHAMIAN, G.A. FEWINGS, P.J. GOUGH, N.A. READER \& P.V. VARALLO. 2010. Environment Agency Fish Pass Manual: Guidance Notes on the Legislation, Selection and Approval of Fish Passes in England and Wales. Document-GEHO 0910 BTBP-E-E. Environment Agency. Bristol, England. United Kingdom. http://publications.environment-agency. gov.uk.

BARBOUR, M.T., J. GERRITSEN, B.D. SNYDER \& J.B. STRIBLING. 1999. Rapid Bioassessment Protocols for Use in Streams and Wadeable Rivers: Periphyton, Benthic Macroinvertebrates and Fish, Second Edition. EPA 841-B-99-002. U.S. Environmental Protection Agency; Office of Water. Washington, D.C. USA. https://www.epa.gov/ aboutepa/about-office-water\#wetlands

BAUDOIN, J.M., V. BURGUN, M. CHANSEAU, M. LARINIER, M. OVIDIO, W. SREMSKI, P. STEINBACH \& B. VOEGTLE. 2014. Assessing the passage of obstacles by fish. Concepts, design and application. Onema. France. http://www. onema.fr/sites/default/files/CPA-ICE-integralite-jui 1let2014.pdf

BRUSLÉ, J. \& J. P. QUIGNARD. 2001. Biologie des poissons d'eau douce européens. Editions Tec\&Doc. Paris. France.

CLAVERO, M., F. BLANCO-GARRIDO \& J. PRENDA. 2006. Monitoring small fish populations in streams: a comparison of four passive methods. Fisheries research, 78: 243-251, doi: 10.1016/j. fishres.2005.11.016.

CLAVERO, M., Q. POU-ROVIRA, L. ZAMORA \& J. NASPLEDA. 2008. Els peixos i la llúdriga a la Garrotxa: poden esdevenir una eina per avaluar la qualitat ambiental?. Beques d'Investigació en Ciències Naturals Ciutat d'Olot. Convocatòria 2006. Olot. Catalonia.

DOADRIO, I. (ed.). 2001. Atlas y libro rojo de los peces continentales de España. Consejo Superior de Investigaciones Científicas. Ministerio de Medio Ambiente. Madrid. Spain, doi: 10.15468/bva6tr.

FERRER, D., R. GARCÍA \& L. XIFRA. 2009. Estudi de la connectivitat longitudinal del riu Fluvià i la seva aplicació per a la gestió de l'anguila europea (Anguilla anguilla) (Technical report). University of Girona. Girona. Catalonia.

GEBLER, R.J. 1998. Examples of near-natural fish passes in Germany: Drop structure conversions, fish ramps and bypass channels. In: Jungwirth, M., S. Schmutz \& S. Weiss (eds). Fish migration 
and Fish Bypasses. Fishing News Books, Blackwell Science Ltd. Cambridge, United Kingdom. pp. 403-419.

GOUGH, P., P. PHILIPSEN, P.P. SCHOLLEMA \& H. WANNINGEN. 2012. From sea to source; International guidance for the restoration of fish migration highways. Veendam. The Netherlands. http://www.fromseatosource.com

LARINIER, M. 2002. Location of fishways. Bulletin Français de la Pêche et de la Pisciculture, 346 suppl.: 39-53, doi: 10.1051/kmae/2002106.

LEUNDA, P.M., R. MIRANDA \& J. OSCOZ. 2010. Piscardo-Phoxinus bigerri. In: Enciclopedia Virtual de los Vertebrados Españoles. A. Salvador \& B. Elvira (Eds.). Sociedad de Amigos del MNCNMuseo Nacional de Ciencias Naturales-CSIC. Madrid. Spain. http://www.vertebradosibericos.org

LUCAS, M.C. \& E. BARAS. 2001. Migration of Freshwater Fishes. Blackwell Science. Oxford. United Kingdom. Doi: 10.1002/9780470999653. fmatter

MARMULLA, G. \& R. WELCOMME (eds.). 2002. Fish passes. Design, dimensions and monitoring. Food and Agriculture Organization of the United Nations (FAO) \& Deutscher Verband für Wasserwirtschaft und Kulturvau (DVWK). Roma. Italy. http://www.doc.govt.nz/Documents/conservation/ native-animals/Fish/fish-passage/fish-passes.pdf

MUNNÉ, A., C. SOLÀ \& N. PRAT. 1998. QBR: Un índice para la evaluación de los ecosistemas de ribera. Tecnología del agua, 175: 20-37.

NADAL-FORTIÀ, J. 1964. La pesca fluvial en Gerona. Ediciones del G.E. y E.G. Girona. Catalonia.

ORDEIX, M., Q. POU-ROVIRA, N. SELLARÈS, M. BARDINA, A. CASAMITJANA, C. SOLÀ \& A. MUNNÉ. 2011. Fish pass assessment in the Rivers of Catalonia (NE Iberian Peninsula). A case study of weirs associated with hydropower plants and gauging stations. Limnetica, 30(2): 405-426. http://www.limnetica.com/documentos/limnetica/ limnetica-30-2-p-405.pdf

PARDO, I., M. ÁLVAREZ, J. CASAS, J.L. MORENO, S. VIVAS, N. BONADA, J. ALBA-TERCEDOR, P. JAIMEZ-CUELLAR, G. MOYÀ, N. PRAT, S. ROBLES; M.L. SUÁREZ; M. TORO \& M.R. VIDAL-ALBARCA. 2002. El hàbitat de los ríos mediterráneos. Diseño de un índice de diversidad de hàbitat. Limnetica, 21: 115-133. http://www.lim netica.com/Limnetica/Limne21/L21b175_Indice_ IBMWP_estado_ecologico_rios_mediterraneos_ibe ricos.pdf
PLAFKIN, J.L., M.T. BARBOUR, K.D. PORTER, S.K. GROSS \& R.H. HUGHES. 1989. Rapid Bioassessment Protocols for use in Streams and Rivers: Benthic Macroinvertebrates and Fish. U.S. Environmental Protection Agency, Office of Water Regulations and Standards, Washington, D.C. EPA 444/4-89-001. USA. http://www.krisweb.com/bi blio/gen_usepa_barbouretal_1999_rba.pdf

PONCIN, P. 1994. 4 Years research on the reproductive-behavior and hybridization of Barbus barbus and Barbus meridionalis. Bulletin Français de la Pêche et de la Pisciculture, 334: 169-176.

PRIGNON, C., J.C. MICHA \& A. GILLET. 1998. Biological and environmental characteristics of fish passage at the Tailfer dam on the Meuse river Belgium. pp. 69-84. In: Fish migration and Fish Bypasses. Jungwirth, M., S. Schmutz \& S. Weiss (eds.). 1998. Fishing News Books, Blackwell Science Ltd. Cambridge. United Kingdom.

R DEVELOPMENT CORE TEAM. 2012. R: A language and environment for statistical computing. $\mathrm{R}$ Foundation for Statistical Computing. Vienna. Austria. Platform: i386-pc-mingw32/i386 (32-bit), URL. http://www.R-project.org

RONI, P. (ed.). 2005. Monitoring Stream and Watershed Restoration. American Fisheries Society. Bethesda, Maryland. USA. Doi: 10.1086/501303.

SANTO, M. 2005. Dispositivos de passagem para peixes em Portugal. Direcçao-Geral dos Recursos Florestais. Editideias-Ediçao e Produçao, Lda. Lisboa. Portugal.

SANTOS, J.M., M.T. FERREIRA, F.N. GODINHO \& J. BOCHECHAS. 2005. Efficacy of nature-like bypass channel in a Portuguese lowland river. Journal of Applied Ichthyology, 21(5): 381-388, doi: 10.1111/j.1439-0426.2005.00616.x

SANTOS, J.M., M.T. FERREIRA, A.N. PINHEIRO \& J. BOCHECHAS. 2006. Effects of small hydropower plants on fish assemblages in mediumsized streams in central and northern Portugal. Aquatic Conservation: Marine and Freshwater Ecosystems, 16: 373-388, doi: 10.1111/j.1439-0426. 2005.00616.x

SANTOS, J.M., A. SILVA, C. KATOPODIS, P. PINHEIRO, A. PINHEIRO, J. BOCHECHAS \& M.T. FERREIRA. 2012. Ecohydraulics of pool-type fishways: Getting past the barriers. Ecological Engineering, 48: 38-50, doi: 10.1016/j.ecoleng.2011. 03.006.

SANZ, F.J., F.J. BRAVO-CÓRDOBA, A. GARCÍAVEGA, \& A. MARTÍNEZ DE AZAGRA. 2013. 
Pasos para peces: escalas y otros dispositivos de paso. Notas técnicas del CIREF, 7. Centro Ibérico de Restauración Fluvial. https://www.dropbox.com /s/yx11ryv4iysqiv7/7_Nota_6-2013_Pasos.pdf

SOLÀ, C., M. ORDEIX, Q. POU-ROVIRA, N. SELLARÈS, A. QUERALT, M. BARDINA, A. CASAMITJANA \& A. MUNNÉ. 2011. The longitudinal connectivity in hydromorphological quality assessments of rivers. The ICF index: A river connectivity index and its application to Catalan rivers. Limnetica, 30(2): 273-292. http://www.lim netica.com/documentos/limnetica/limnetica-30-2p-273.pdf

SOSTOA, A. DE, R. ALLUÉ, C. BAS, F. CASALS, J. CASAPONSA, M. CASTILLO \& I. DOADRIO. 1990. Peixos. Història Natural dels Països Catalans, 12. Enciclopèdia Catalana, SA. Barcelona. Catalonia.

SOSTOA, A. DE, N. M. CAIOLA, F. CASALS, E. GARCÍA-BERTHOU, C. ALCARAZ, L. BENEJAM, A. MACEDA, C. SOLÀ \& A. MUNNÉ. 2010. Ajust de l'índex d'Integritat Biòtica (IBICAT) ba- sat en l'ús dels peixos com a indicadors de la qualitat ambiental als rius de Catalunya. Agència Catala de l'Aigua, Departament de Medi Ambient i Habitatge, Generalitat de Catalunya. Barcelona. Catalonia.

TRAVADE, F. \& M. LARINIER. 2002. Monitoring techniques for fishways. Bulletin Français de la Pêche et de la Pisciculture, 346 suppl.: 166-180, doi: $10.1051 / \mathrm{kmae} / 2002101$

VILA-GISBERT, A., L. ZAMORA \& R. MORENOAMICH. 2000. Use of condition of Mediterranean barbel (Barbus meridionalis) to assess habitat quality in stream ecosystems. Archiv für Hydrobiologie, 148: 135-145.

ZAMORA, L. 2011. Barbo de montaña-Barbus meridionalis. In: Enciclopedia Virtual de los Vertebrados Españoles. Salvador, A. \& B. Elvira (eds.). Sociedad de Amigos del MNCN-Museo Nacional de Ciencias Naturales-CSIC. Madrid. Spain. http:// www.vertebradosibericos.org

ZIPPIN, C. 1958. The removal method of population estimation. Journal of Wildlife Management, 22: 82-90. 